\title{
Lafutidine Changes Levels of Somatostatin, Calcitonin Gene-Related Peptide, and Secretin in Human Plasma
}

\author{
Hiroki IтоH, ${ }^{*}$ Takafumi NAIto, and Masaharu TAKEYAMA \\ Department of Clinical Pharmacy, Oita Medical Univercity, Hasama-machi, Oita 879-5593, Japan. \\ Received October 22, 2001; accepted November 12, 2001
}

\begin{abstract}
We examined the effects of the histamine $\mathrm{H}_{2}$-receptor antagonist, lafutidine, on the levels of gastrointestinal peptides (somatostatin, calcitonin gene-related peptide (CGRP), gastrin, secretin, and motilin) in plasma from healthy subjects. After a single oral administration of lafutidine $(10 \mathrm{mg})$, the plasma lafutidine level (186士 $13.4 \mathrm{ng} / \mathrm{ml}$ ) was highest in the $60-\mathrm{min}$ sample after administration and then the plasma level fell. Lafutidine caused significant increase in plasma somatostatin levels at 20 to $120 \mathrm{~min}$ and in CGRP levels at 40 to $120 \mathrm{~min}$, compared with a placebo group. The physiological release of plasma secretin was reduced by administration of lafutidine, but the medicine did not alter the level of gastrin or motilin. These results suggest that the pharmacological effects of lafutidine on regulation of gastrointestinal functions closely relate to changes of somatostatin-, CGRP- and secretin-immunoreactive substance levels in human plasma.
\end{abstract}

Key words lafutidine; somatostatin; CGRP; gastrin; secretin; motilin

Histamine $\mathrm{H}_{2}$-receptor antagonists $\left(\mathrm{H}_{2}\right.$-antagonists), widely used in the treatment of peptic ulcers, gastrophageal reflux diseases and gastritis, are potent inhibitors of gastric acid secretion. ${ }^{1-3)}$ We previously confirmed that ranitidine and nizatidine cause significant increase in the level of motilin, a powerful inducer of gastrointestinal motor activity, in human plasma. ${ }^{4)}$ In addition, it has been shown that ranitidine and nizatidine have anti-acetylcholinesterase activity with significantly accelerated gastric emptying. ${ }^{5,6)}$ These results indicate that motilin release after an administration of ranitidine or nizatidine may relate to an effect on gastrointestinal motility. However, ulcer relapse has become a clinical problem after cessation of these $\mathrm{H}_{2}$-antagonists because of the fragility of the mucosal defensive factors. ${ }^{7)}$ Recently a newly synthesized anti-ulcer drug, lafutidine, 2-(furfurylsulfinyl)- $N$-(4-[4(piperidinomethyl)-2-pyridyl]oxy-(Z)-2-butenyl) acetamide, was developed as a second-generation $\mathrm{H}_{2}$-antagonist with an increased action on the gastric mucosal defensive capacity. ${ }^{8)}$ Lafutidine has potent and long-lasting acid antisecretory activities in rats and dogs. ${ }^{9}$ It also affects gastrointestinal functions by regulating gastrointestinal motility. ${ }^{10,11)}$ Its effects on gastrointestinal function are mainly regulated by hormonal and neuronal mechanisms, however, the mechanism is not clear. Therefore, we examined the plasma levels of brain-gut peptides which regulate gastrointestinal function.

Somatostatin inhibits the secretion of motilin, gastrin, and secretin, and participates in regulating gastrointestinal motility. ${ }^{12-17)}$ Calcitonin gene-related peptide (CGRP) is known to inhibit acid secretion and to stimulate mucosal blood flow. ${ }^{18-20)}$ Gastrin stimulates acid secretion and gastrin release is mediated by various mechanisms. ${ }^{21)}$ Secretin inhibits gastrointestinal motility; it inhibits gastric acid secretion and stimulates pancreatic secretion. ${ }^{22}$ ) Motilin has powerful fundic pouch motor-stimulating activity ${ }^{23)}$ and is one of the most important factors controlling the regular occurrence of phase-3 contractions of the migrating motor complex (MMC). ${ }^{24,25)}$ The purpose of this study was to determine the effects of lafutidine on the plasma levels of somatostatin-, CGRP-, gastrin-, secretin-, and motilin-immunoreactive substances (IS) in healthy subjects.

\section{MATERIALS AND METHODS}

Materials Lafutidine was purchased from UCB Japan (Tokyo, Japan). Lactose (Merck Hoei Co., Ltd., Osaka, Japan) was used as placebo. Synthetic somatostatin, CGRP, gastrin I(G17), secretin, and motilin were purchased from Peptide Institute, Inc. (Osaka). An antiserum to somatosatin was purchased from Cambridge Res. Biochem. (Cambridge, U.K.). An antiserum to motilin (Y121) was obtained from Peptide Institute, Inc. (Osaka). Antisera to gastrin (A600R1B), CGRP, and secretin (A603/1B) were purchased from Biogenesis, Ltd. (Poole, U.K.). All other reagents were reagent grade and commercially available.

Subjects Five healthy male volunteers (non-smokers), aged 23-31 (median 27 years), participated in this study. Each subject received information about the study's scientific purpose, which was approved by the Ethics Committee at Oita Medical University, and subsequently gave informed consent. No subject received any medication for a month preceding the test and no stimulator or inhibitor of gastrointestinal motility was administered to any subject during study.

Determination of Lafutidine Levels in Plasma Standard lafutidine was supplied by UCB Japan Co., Ltd. A $1 \mathrm{ml}$ plasma sample was mixed with $0.5 \mathrm{ml}$ of $1 \mathrm{~N} \mathrm{NaOH}$, and was eluted with $3 \mathrm{ml}$ ethyl acetate. The eluate was evaporated to dryness under reduced pressure. The residue was dissolved in $1 \mathrm{ml}$ of $0.1 \mathrm{~N} \mathrm{HCl}$, and washed with $1 \mathrm{ml}$ of ethyl acetate. After the aqueous phase was added $0.75 \mathrm{ml}$ of $1 \mathrm{~N} \mathrm{NaOH}$, and lafutidine was eluted with $3 \mathrm{ml}$ ethyl acetate containing $20 \mathrm{ng}$ 4-amino-3-nitroanisole as an internal standard. The eluate was evaporated to dryness and reconstituted in a $200-\mu 1$ mobile phase, and the solution was injected onto a chromatograph. HPLC was carried out using a guard-Pak precolumn and a C18 column (Cosmosil 5C18-AR, Nacalai Tesque, Kyoto, Japan) at $40{ }^{\circ} \mathrm{C}$ and UV absorbance was detected at $230 \mathrm{~nm}$. Acetonitrile-10 mM phosphate buffer pH $5.9(20: 80)$ was used as the mobile phase at a flow rate of $1 \mathrm{ml} / \mathrm{min}$.

Study Schedules Lafutidine at a dose of $20 \mathrm{mg}$, or placebo was administered orally with $100 \mathrm{ml}$ of water. Venous blood samples from a forearm vein were taken before 
and at $20,40,60,90,120,180$, and $240 \mathrm{~min}$ after administration of the drug. All subjects ate lunch between 11:45 and $12: 00$ and the study was carried out from $14: 00$ ( $2 \mathrm{~h}$ after lunch) until $18: 00$.

Preparation of Plasma Extracts The blood samples were placed in chilled tubes containing 500 kallikrein inhibitor units $/ \mathrm{ml}$ of aprotinin and $1.2 \mathrm{mg} / \mathrm{ml}$ of EDTA. After centrifugation, plasma samples were diluted with $4 \%$ acetate buffer, $\mathrm{pH} 4.0$, and loaded onto Sep-Pak ${ }^{\circledR}$ C18 cartridges (Millipore Co., Massachusetts, U.S.A), and washed with 4\% acetate buffer. The peptides in plasma were eluted with $70 \%$ acetonitrile in $0.5 \%$ acetate buffer, $\mathrm{pH} 4.0$, lyophilized, and stored at $-40{ }^{\circ} \mathrm{C}$ until used. The recovery of plasma somatostatin-, CGRP-, gastrin-, secretin-, and motilin was $>93 \%$ with this extraction procedure (data not shown).

Enzyme Immunoassays for Somatostatin-, CGRP-, Gastrin-, Secretin-, and Motilin-Immunoreactive Substances Peptide levels in plasma were measured using a highly sensitive enzyme immunoassay for somatostatin-, ${ }^{26}$ ) CGRP-, ${ }^{27)}$ gastrin-, ${ }^{28)}$ secretin- ${ }^{29)}$ and motilin- ${ }^{30)}$ as previously described. The assay was performed by a delayed addition method. Separation of bound and free antigen was performed on an anti-rabbit IgG (55641, ICN Pharmaceuticals, Inc., Ohio, U.S.A.) coated immunoplate (Nunc-Immuno Module Maxisorp F8, InterMed, Denmark). Human somatostatin, CGRP, mini gastrin I, secretin, and porcine motilin were conjugated with $\beta$-galactosidase by $N$ - $(\varepsilon$-maleimidocaproyloxy)-succinimide according to the methods of Kitagawa et al. $^{31)}$ The enzyme immunoassays for somatostatin-, CGRP-, gastrin-, secretin-, and motilin-immunoreactive substances were specific and highly sensitive to detection limits of $0.10,1.0,0.04,1.7$, and $0.80 \mathrm{fmol} / \mathrm{ml}$, respectively.

Data Analysis All values are expressed as means \pm S.D. Comparison of mean values was made by analysis of variance and Dunnett's test. A value of $p<0.05$ was regarded as significant.

\section{RESULTS AND DISCUSSION}

Lafutidine is a novel antiulcer drug with potent antisecretory and gastroprotective activities. ${ }^{9,32)}$ It also treats gastrointestinal functions by regulating gastrointestinal motility. ${ }^{10,11)}$ In this study, gut-regulated peptide (somatostatin, CGRP, gastrin, secretin, and motilin) levels, which regulate gastrointestinal function, were examined to study their relation with lafutidine.

The profiles of average plasma lafutidine concentrations against time after oral administration $20 \mathrm{mg}$ of the drug are shown in Fig. 1. The plasma level $(186 \pm 13.4 \mathrm{ng} / \mathrm{ml})$ was highest in the $60 \mathrm{~min}$ sample. After oral administration of a lactose tablet (placebo), somatostatin, CGRP, motilin, gastrin and secretin levels were within baseline levels thoughout the 300-min study period (Fig. 2).

Somatostatin acts as an inhibitor of hormone (motilin, gastrin, and secretin) release. Time course of somatostatin-IS plasma level after lafutidine administration is shown in Fig. 2a. Lafutidine caused significant increase in somatostatin-IS at 20-120 min compared with placebo. The release of somatostatin $\left(A U C_{0 \rightarrow 240 \mathrm{~min}}\right)$ increased by $33.9 \%$ with lafutidine (vs. placebo) (Table 1). Mclntosh et al. ${ }^{33)}$ noted that administration of cimetidine decreased the somatostatin release,

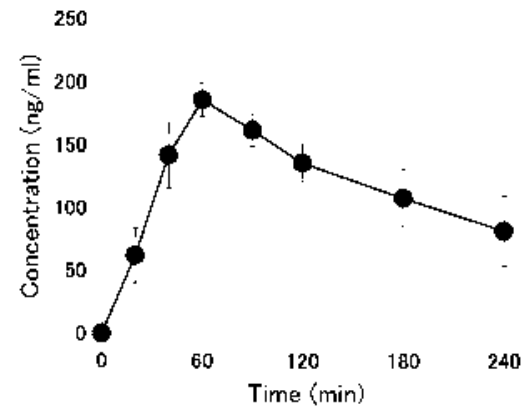

Fig. 1. Plasma Lafutidine Levels after Oral Administration of $20 \mathrm{mg}$ of the Drug

Each value represents the mean \pm S.D. of concentrations in five male volunteers.

Table 1. The Amounts of Peptides Released after Administration of Lafutidine to Healthy Volunteers

\begin{tabular}{lcc}
\hline \hline & $\begin{array}{c}\text { Placebo } \\
(\mathrm{pg} \cdot \mathrm{min} / \mathrm{ml})\end{array}$ & $\begin{array}{c}\text { Rafutidine } \\
(\mathrm{pg} \cdot \mathrm{min} / \mathrm{ml})\end{array}$ \\
\hline Somatostatin & $1345.2 \pm 157.7$ & $1776.2 \pm 171.9^{* *}$ \\
CGRP & $5769.0 \pm 351.7$ & $7475.0 \pm 409.6^{* *}$ \\
Gastrin & $6956.0 \pm 476.8$ & $6758.0 \pm 281.5$ \\
Secretin & $838.1 \pm 88.6$ & $341.1 \pm 67.1 * *$ \\
Motilin & $2625.5 \pm 61.1$ & $2573.1 \pm 39.4$ \\
\hline
\end{tabular}

Each value represents the mean \pm S.D. of concentration in five tests. $* * p<0.01$ compared with placebo.

while Takeyama et $a l^{4)}$ reported that cimetidine did not affect plasma somatostatin levels. In this study, some pathways had enhanced somatostatin-IS levels by lafutidine. Somatostatin is released from D cells in the mucosa of the stomach, ${ }^{34}$ and participates in regulating gastrointestinal function. ${ }^{12-17)}$ Furthermore, the time to peak plasma lafutidine levels after administration of the drug was $60 \mathrm{~min}$. Single administration of lafutidine caused a significant increase of plasma somatostatin in accordance with the plasma lafutidine levels. From this result, it can be assumed that lafutidine affects gastrointestinal mobility via an increase in somatostatin secretion.

The action of CGRP in the stomach includes stimulation of gastric blood flow, ${ }^{20)}$ inhibition of motility, ${ }^{19)}$ and inhibition of gastric acid secretion. ${ }^{18)}$ Time course of CGRP-IS plasma level after lafutidine administration is shown in Fig. 2b. Lafutidine caused significant increase in CGRP-IS at 40-120 min compared with placebo. The release of CGRP $\left(A U C_{0 \rightarrow 240 \mathrm{~min}}\right)$ increased by $30.2 \%$ with lafutidine (vs. placebo) (Table 1). The released CGRP by lafutidine administration may produce a gastroprotective effect, increase mucosal blood flow, and inhibit acid secretion in the gastrointestinal tract by stimulating CGRP-containing nerves.

The plasma gastrin levels after administration of lafutidine are shown in Fig. 2c. The drug had no significant effect on plasma gastrin-IS level; generally, gastrin is secreted as a result of stimulation of the gastric mucosal G cells.

Time course of secretin-IS plasma level after lafutidine administration is shown in Fig. 2d. We previously reported that postprandial rises in plasma secretin were prevented after administration of cimetidine and ranitidine. ${ }^{4)}$ But Bell et al. ${ }^{35)}$ reported that cimetidine failed to suppress plasma secretin like immunoreactivity. In our study, the physiological rises in 
(a)

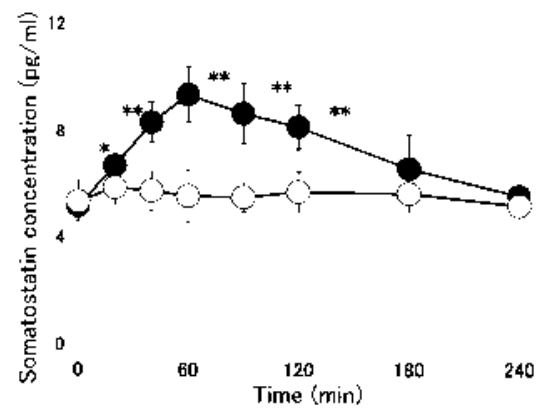

(b)

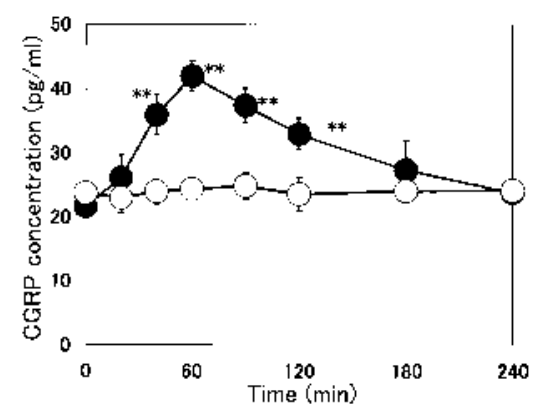

(c)

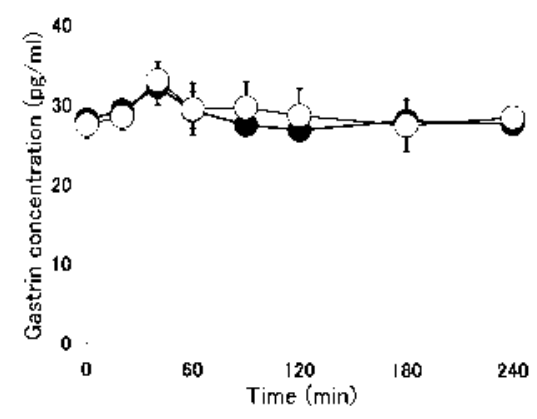

(d)

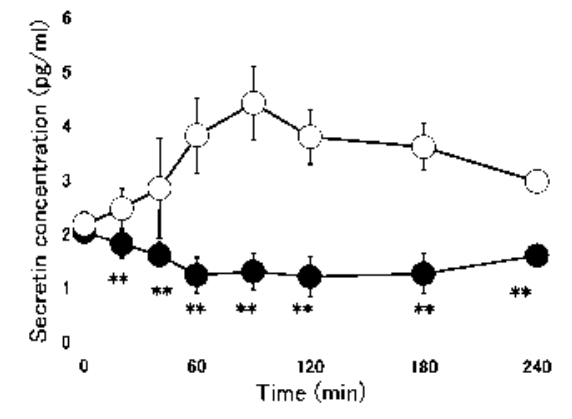

(e)

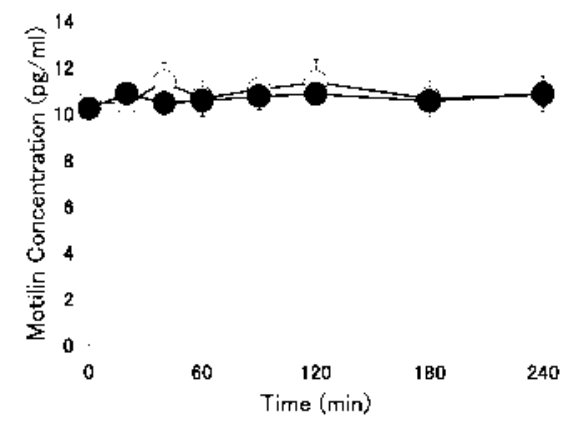

Fig. 2. Plasma Somatostatin- (a), CGRP- (b), Gastrin- (c), Secretin- (d), and Motilin- (e) IS Levels after Oral Administration of Lafutidine (-) or Placebo $(O)$

Each value represents the mean \pm S.D. of levels in five male volunteers. $* * p<0.01$ and $* p<0.05$ compared with placebo. plasma secretin (placebo administration) were reduced after administration of lafutidine even though lafutidine was administered $2 \mathrm{~h}$ after lunch. The release of secretin decreased by $59.3 \%$ with lafutidine (Table 1 ). This was due to suppression of gastric acid secretion. ${ }^{22)}$

Motilin is a powerful inducer of gastrointestinal motor activity in the fundus and the antral pouch of the stomach. We previously reported that ranitidine and nizatidine raise the levels of motilin-IS in human plasma. ${ }^{4)}$ Both have antiacetyl-cholinesterase activity, and might raise acetylcholine levels. ${ }^{5,6}$ Muscarinic receptors are present on the membrane of motilin-secreting cells and acetylcholine is a major regulator of motilin release. ${ }^{36,37)}$ The plasma motilin levels after administration of lafutidine are shown in Fig. 2e. In this study, lafutidine had no effect on motilin levels; it probably has no anti-acetyl-cholinesterase activity.

Lafutidine has a cytoprotection effect and treats gastrointestinal functions by regulating gastrointestinal motility. ${ }^{10,11)}$ Our studies of gut hormone levels add one viewpoint on mechanism of lafutidine. In conclusion, ingestion of lafutidine causes changes in the plasma levels of somatostatin-IS, CGRP-IS, and secretin-IS. We hypothesize that its gastrointestinal effects might be closely related to changes in somatostatin, CGRP and secretin plasma levels, which are related to the regulation of gastrointestinal function.

\section{REFERENCES}

1) Ueki S., Seiki M., Yoneta T., Aita H., Chaki K., Hori Y., Morita H., Tagashira E., Itoh Z., J. Pharmacol. Exp. Ther., 264, 152-157 (1992).

2) Black J. W., Duncan W. A., Durant C. J., Ganellin C. R., Parsons E. M., Nature (London), 236, 385-390 (1972).

3) Daly M. J., Humphray J. M., Stables R., Br. J. Pharmacol., 72, 55-60 (1981).

4) Takeyama M., Itoh H., Hayashi T., Nagano T., Pharm. Pharmacol. Commun., 4, 591-594 (1998).

5) Bertaccini G., Scarpignato C., Br. J. Pharmacol., 77, 443-448 (1982).

6) Ueki S., Seiki M., Yoneta T., Aita H., Chaki K., Hori Y., Morita H., Tagashira E., Itoh Z., J. Pharmacol. Exp. Ther., 264, 152-157 (1992).

7) Martin D. F., Hollanders D., May S. J., Ravenscroft M. M., Tweedle D. E., Miller J. P., Lancet, 1, 7-10 (1981).

8) Hirakawa N., Matsumoto H., Hosoda A., Sekine A., Yamaura T., Sekine Y., Chem. Pharm. Bull., 46, 616-622 (1998).

9) Shibata M., Yamaura T., Inaba N., Onodera S., Chida Y., Ohnishi H., Eur. J. Pharmacol., 235, 245-253 (1993).

10) Ajioka H., Miyake H., Matsuura N., Pharmacology, 61, 83-90 (2000).

11) Ichikawa T., Ishihara K., Shibata M., Yamaura T., Saigenji K., Hotta K., Eur. J. Pharmacol., 297, 87-92 (1996).

12) Peeters T. L., Janssens J., Vantrappen G. R., Regul. Pept., 5, 209-217 (1983).

13) Poitras P., Steinbach J. H., VanDeventer G., Code C. F., Walsh J. H., Am. J. Physiol., 239, G215-220 (1980).

14) Thor P., Krol R., Konturek S. J., Coy D. H., Schally A. V., Am. J. Physiol., 235, E249-254 (1978).

15) Hostein J., Janssens J., Vantrappen G., Peeters T. L., Vandeweerd M., Leman G., Gastroenterology, 87, 1004-1008 (1984).

16) Seal A., Yamada T., Debas H., Hollinshead J., Osadchey B., Aponte G., Walsh J., Am. J. Physiol., 243, G97-102 (1982).

17) Johanssson C., Efendic S., Wisen O., Uvnas-Wallensten S., Luft R., Scand. J. Gastroenterol., 13, 481-483 (1978).

18) Tache Y., Pappas T., Lauffenburger M., Goto Y., Walsh J. H., Debas H., Gastroenterol., 87, 344-349 (1984).

19) Katsoulis S., Conlon J. M., Eur. J. Pharmacol., 162, 129-134 (1989).

20) Bauerfeind P., Hof R., Hof A., Cucala M., Siegrist S., von Ritter C., Fischer J. A., Blum A. L., Am. J. Physiol., 256, G145-149 (1989).

21) Matsuno M., Matsui T., Iwasaki A., Arakawa Y., J. Gastroenterol., 32, 
579-586 (1997).

22) Chey W. Y., Lee Y. H., Hendricks J. G., Rhodes R. A., Tai H.-H., Am. J. Dig. Dis., 23, 981-988 (1978).

23) Brown J. C., Parkes C. O., Gastroenterology, 53, 731-736 (1967).

24) Itoh Z., Honda R., Hiwatashi K., Takeuchi S., Aizawa I., Takayanagi R., Couch E. F., Scand. J. Gastroenterol. Suppl., 39, 93-110 (1976).

25) You C. H., Chey W. Y., Lee K. Y., Gastroenterology, 79, 62-66 (1980).

26) Takeyama M., Yanaga N., Yarimizu K., Ono J., Takaki R., Fujii N., Yajima H., Chem. Pharm. Bull., 38, 456-459 (1990).

27) Nagano T., Ikawa K., Takeyama M., Jpn. J. Hosp. Pharm., 24, 363369 (1998)

28) Takeyama M., Matsuo H., Mori K., Chem. Pharm. Bull., 41, 21972199 (1993)

29) Itoh H., Nagano T., Hayashi T., Takeyama M., Jpn. J. Hosp. Pharm., 25, 162-168 (1999).
30) Takeyama M., Asakura S., Kawano A., Mori K., Biol. Pharm. Bull., 17, 440-442 (1994).

31) Kitagawa T., Shimozono T., Aikawa T., Yoshida T., Nakamura H., Chem. Pharm. Bull., 29, 1130-1133 (1981).

32) Onodera S., Shibata M., Tanaka M., Inaba N., Yamaura T., Ohnishi H., Jpn. J. Pharmacol., 68, 161-173 (1995).

33) Mclntosh C. H., Bakich V., Kwok Y. N., Wong J., Brown J. C., Regul. Pept., 19, 253-263 (1987).

34) Rufener C., Dubois M. P., Malaisse L. F., Oric L., Diabetologia, 11, 321-324 (1975).

35) Bell P. M., Henry R. W., Buchanan K. D., Alberti K. G., Regul. Pept., 10, 127-131 (1985).

36) Fox J. E. T., Daniel E. E., Jury J., Track N. S., Chiu S., Can. J. Physiol. Pharmacol., 61, 1042-1049 (1983).

37) Poitras P., Dumont A., Cuber J. C., Trudel L., Peptides, 14, 207-213 (1993). 